\title{
Assessment of Climate Change Impact on Water Resources in the Upper Senegal Basin (West Africa)
}

\author{
Mamadou Lamine Mbaye ${ }^{1,2^{*}}$, Stefan Hagemann ${ }^{3}$, Andreas Haensler ${ }^{4}$, Tobias Stacke ${ }^{3}$, \\ Amadou Thierno Gaye ${ }^{2}$, Abel Afouda ${ }^{1}$ \\ ${ }^{1}$ West African Science Service Center on Climate Change and Adapted Land Use, FAST/UAC, Cotonou, Benin \\ ${ }^{2}$ Laboratoire de Physique de L'Atmosphere et de I'ocean, Ecole Superieure Polytechnique, Dakar-Fann, \\ Senegal \\ ${ }^{3}$ Max Planck Institute for Meteorology, Hamburg, Germany \\ ${ }^{4}$ Climate Service Center, Hamburg, Germany \\ Email: mamadoulamine.mbaye@ucad.edu.sn
}

Received 2 November 2014; accepted 5 February 2015; published 23 March 2015

Copyright (C) 2015 by authors and Scientific Research Publishing Inc.

This work is licensed under the Creative Commons Attribution International License (CC BY).

http://creativecommons.org/licenses/by/4.0/

(c) $($ ) 0 pen Access

\section{Abstract}

This study assesses the potential impacts of climate change on water resources and the effect of statistical bias correction on the projected climate change signal in hydrological variables over the Upper Senegal Basin (West Africa). Original and bias corrected climate data from the regional climate model REMO were used as input for the Max Planck Institute for Meteorology-Hydrology Model (MPI-HM) to simulate river discharge, runoff, soil moisture and evapotranspiration. The results during the historical period (1971-2000) show that using the bias corrected input yields a better representation of the mean river flow regimes and the $10^{\text {th }}$ and $90^{\text {th }}$ percentiles of river flow at the outlet of the Upper Senegal Basin (USB). The Nash-Sutcliffe efficiency coefficient is 0.92 using the bias corrected input, which demonstrates the ability of the model in simulating river flow. The percent bias of $3.88 \%$ indicates a slight overestimation of the river flow by the model using the corrected input. The evaluation demonstrates the ability of the bias correction and its necessity for the simulation of historical river regimes. As for the potential changes of hydrological variables by the end of $21^{\text {st }}$ century (2071-2100), a general decrease of river discharge, runoff, actual evapotranspiration, soil moisture is found under two Representative Concentration Pathways (RCP4.5 and RCP8.5) in all simulations. The decrease is higher under RCP8.5 with uncorrected data in the northern basin. However, there are some localized increases in some parts of the basin (e.g. Guinean Highlands). The projected climate change signal of these above variables has the same spatial pattern and tendency for the uncorrected and bias corrected data although the magnitude of the corrected signal is somewhat lower than that uncorrected. Furthermore, the

\footnotetext{
"Corresponding author.
}

How to cite this paper: Mbaye, M.L., Hagemann, S., Haensler, A., Stacke, T., Gaye, A.T. and Afouda, A. (2015) Assessment of Climate Change Impact on Water Resources in the Upper Senegal Basin (West Africa). American Journal of Climate Change, 4, 77-93. http://dx.doi.org/10.4236/ajcc.2015.41008 
available water resources are projected to substantially decrease by more than $-50 \%$ in the majority of the basin (especially in driest and hottest northern basin with RCP8.5 scenario) for all data, except the Guinean highlands where no change is projected. The comparison of simulations driven with uncorrected and bias corrected input reveals that the bias correction does not substantially change the signal of future changes of hydrological variables for both scenarios over the USB even though there are differences in magnitude and deviations in some parts of the basin.

\section{Keywords}

Climate Change Impact, Signal, Bias Correction, Upper Senegal Basin, Water Resources

\section{Introduction}

Long-term observational records and climate projections provide abundant evidence that freshwater resources are vulnerable and have the potential to be strongly impacted by climate change, with wide-ranging conesquences for human societies and ecosystems [1]. These consequences are more severe in regions dominated by arid and semiarid climate such as West Africa (WA). Then, Africa as a whole is one of the most vulnerable continents due to its high exposure and low adaptive capacity [2]. Several impact studies over WA have shown that water resources are significantly impacted by climate change [3]-[9]. For much of Africa, knowledge about recent climate change is limited, due to weak climate monitoring, and gaps in coverage that continue to exist [10]. The well known droughts in the 1970s have led to a decline of water flows in many African river basins. Also, the Senegal River Basin, which is situated in WA, has faced those droughts. Its annual average flow at Bakel (reference station) fell from $1374 \mathrm{~m}^{3} / \mathrm{sec}$ over the period 1903-1950 to $840 \mathrm{~m}^{3} / \mathrm{sec}$ in the period 1950-1972 and further decreased to only $419 \mathrm{~m}^{3} / \mathrm{sec}$ in the period 1973-2002 [11]. The drought has reduced rain-fed agriculture, decreased the seasonal flooding of wetlands, limited economic development, and in the overall, enhanced poverty [12]. Such water shortage has obviously affected the main activities in the basin (agriculture, fishery, hydropower generation, etc.). As water is the agent that delivers many of the impacts of climate change to society, for example to the energy, agriculture, and transport sectors [10], it is fundamental to investigate how climate change will affect this valuable resource in the future. A series of studies has already been carried out over the Senegal River basin in order to analyze the ability of models to simulate the basin's climate, but also to quantify projected climate changes and to identify potential climate change impacts. [3] evaluated the ability of four General Circulation Models (GCMs) to reproduce the basin's climate and they found that all four models failed to reproduce the rainfall volumes in the Sahelian zone, and the seasonal dynamics of rainfall in the Guinean zones. The biases were mainly introduced by the limited quality of the GCM input data, which can also be related to the coarse resolution of the GCMs, which does not allow representing the important small scale processes. Analyzing projected changes, an increase in dry spell length by 2050 was found by [4], and [13] by analyzing regional climate models (RCMs). The higher resolution of RCMs compared to GCMs makes it possible to simulate regional climate features more realistically such as orographic precipitation, extreme events, and regional scale climate anomalies, or non-linear effects [14]. But the climate models (e.g. RCMs) are subject to systematic biases when comparing simulated meteorological variables for the current climate to observations and these biases can affect hydrological simulations considerably [15]. In addition, [16] stated that models will not be able to simulate accurate predictions if the areal precipitation is not adequately represented. To date, there is a lack of impact studies on the seasonal changes of hydrological variables (such as soil moisture, evapotranspiration, and runoff), extreme streamflow changes, and their variability using high resolution climate data as input for a hydrological model over Upper Senegal Basin (USB). However, the better understanding of potential future changes in the spatial and temporal variability of the hydrological cycle is fundamental to inform local societies and water resources managers in order to increase awareness and to support the development of adaptation strategies, and also agricultural productivity which accounts for more than $80 \%$ of the water withdrawals in the basin [12].

In the present study, bias corrected data are used as input for a hydrological model to overcome the well known biases in GCM/RCM output. Taking into account the concern of the potential alteration of the climate 
change signal due to bias correction [17], both uncorrected and bias corrected data from the regional climate model REMO are used to drive the Max Planck Institute for Meteorology-Hydrology model (MPI-HM). The main purposes of this study are to investigate if there is an added value of applying bias correction, to assess the potential changes of hydrological variables and water resources availability, and to explore whether bias correction may affect the climate change signal of projected hydrological variables over the USB.

The study is structured as following: data and methods are described in Section 2; the results and discussion are presented in Section 3; and the conclusion is given in Section 4.

\section{Data and Methods}

\subsection{Upper Basin Senegal}

The current study focuses on the USB in WA (Figure 1). From its source in Guinea the Senegal River flows through the western Sahel region in Mali, Mauritania and Senegal and has a catchment size of about 218,000 $\mathrm{km}^{2}$. Its three main tributaries (Bakoye, Bafing and Faleme) provide over $80 \%$ of its flows and are within the upper basin. The basin is subject to a large north-south precipitation gradient ranging from $200 \mathrm{~mm} /$ year in the north to more than $1800 \mathrm{~mm} /$ year in the south. The predominantly natural vegetation of the region follows this rainfall gradient, ranging from semi-arid savannah in the North to sub-humid forest in the South [18].

Bakel is considered to be the reference station of the Senegal River due to its location below the confluence with the last major tributary (Faleme). At this station, the average annual discharge is about $690 \mathrm{~m}^{3} / \mathrm{sec}$, which corresponds to an annual input of around $22 \times 10^{9} \mathrm{~m}^{3}$. The annual discharge ranges between a minimum of 6.9 $\mathrm{bm}^{3}$ and a maximum of $41.5 \mathrm{bm}^{3}$ [19].

\subsection{Climate Data}

Daily data are taken from a set of simulations (historical and scenario) conducted with the regional climate model REMO [20]. At the model boundaries, the REMO simulations are forced with data from the global climate model MPI-ESM-LR [21] following the RCP4.5 and RCP8.5 emission scenario pathways. REMO data is available in the context of the Coordinated Regional Climate Downscaling Experiment [22] over Africa at 0.44 resolution for the period 1950 to 2100 and it has already been used over Africa [23]-[26]. The data analyses focus on the periods (1971-2000) as reference period and (2071-2100) as scenario period. As precipitation and temperature are the key drivers for the hydrological regime of the river and climate change has its main impact through changes in these two variables [9] both were bias corrected following the method of [27]. Together with radiation, wind and air moisture data, the bias corrected and uncorrected temperatures are then used in the Penman-Monteith equation to estimate the potential evapotranspiration. Evapotranspiration is generally the most substantial component of the water budget, being the pathway for local rainfall recycling, in particular, over the Sahel region [28]. These three variables (precipitation, temperature, and potential evapotranspiration) were used as climate input of the Max Planck Institute for Meteorology-Hydrological Model.

\subsection{The Max Planck Institute for Meteorology-Hydrological Model}

The MPI-HM [29] is a global hydrological model which consists of the Simplified Land Surface (SL) scheme [30] and the Hydrological Discharge (HD) model [31]-[33]. This model is chosen because it has been widely applied in impact studies over many different rivers around the world, including West African rivers [34] [17]-[35]. It uses a half degree resolution $\left(0.5^{\circ}\right)$ and daily time steps. The SL scheme is designed to compute the vertical water fluxes while the HD model computes the lateral water fluxes and river routing on the land surface (Figure 2). The SL scheme uses a soil bucket scheme for the calculation of the vertical water balance. Its output comprises surface runoff and drainage that are used directly by the HD model which is a state of the art river routing model. In the HD model, the lateral water flow is separated into the three flow process of overland flow, base flow and river flow. Overland flow uses surface runoff as input, base flow is fed by drainage from the soil and the inflow from upstream grid boxes contributes to river flow. The sum of the three flow processes equals to the total outflow from a grid box [30]. Initially, the two sub-models were being run separately, this coupled version (MPI-HM) has been constructed by [29] who also implemented a dynamical wetland extent scheme. In this study, neither wetland dynamics are taken into account nor human activities (dams, water withdraw, etc.) nor 


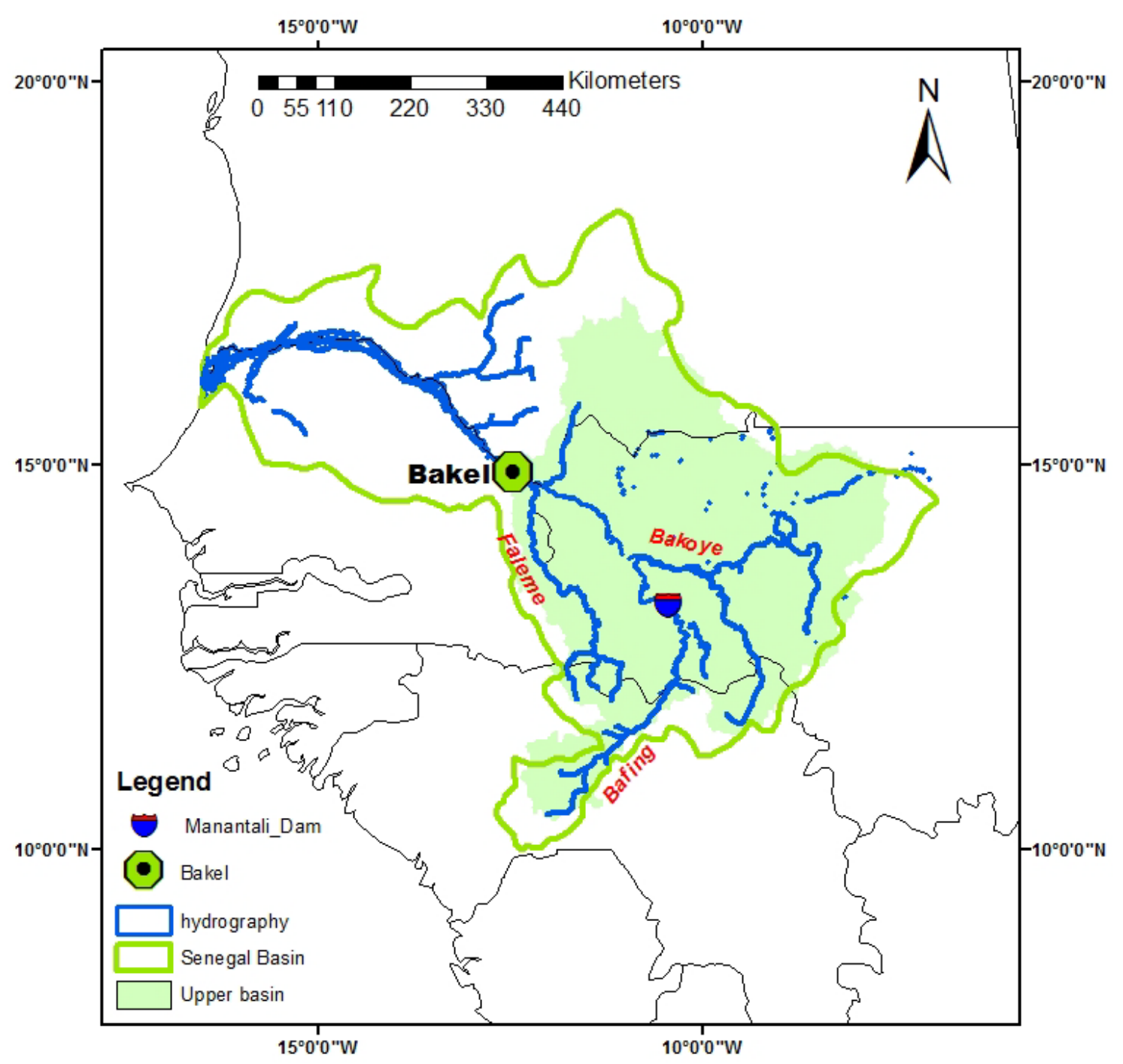

Figure 1. Location of upper senegal basin (green area).

land use changes. The MPI-HM model requires as climate input temperature, precipitation, and potential evapotranspiration fields; it uses land sea mask, glacier mask, total field capacity and plant-available soil water capacity from LSP2 dataset [36] that has recently been updated [37]. The other boundary data are sub-grid slope, elevation, river routing direction, and storage retention times. In this study, the global standard version of the model has been modified to meet the local conditions in USB. The overland flow retention constant, the river flow retention constant, minimum soil moisture threshold for drainage and critical soil moisture for drainage, and the evaporation factor coefficients have been optimized by manual adjustments.

The simulated variables of interest are river discharge, surface runoff, drainage, evapotranspiration, and soil moisture. All simulations were carried out from 1965 to 2100; the first six years of simulations were considered as spin-up and removed from the analysis time series in order to avoid the influence of initial conditions in the water storages. All fluxes are computed at every land surface grid cell for every time step. More details about the functioning of the model can be found in [29] [30]-[33].

\section{Model Performance}

In order to evaluate the performance of the optimized MPI-HM model over the USB, the following statistics are used:

Nash Sutcliffe Efficiency [38] which is commonly used to assess hydrological models goodness fit: 


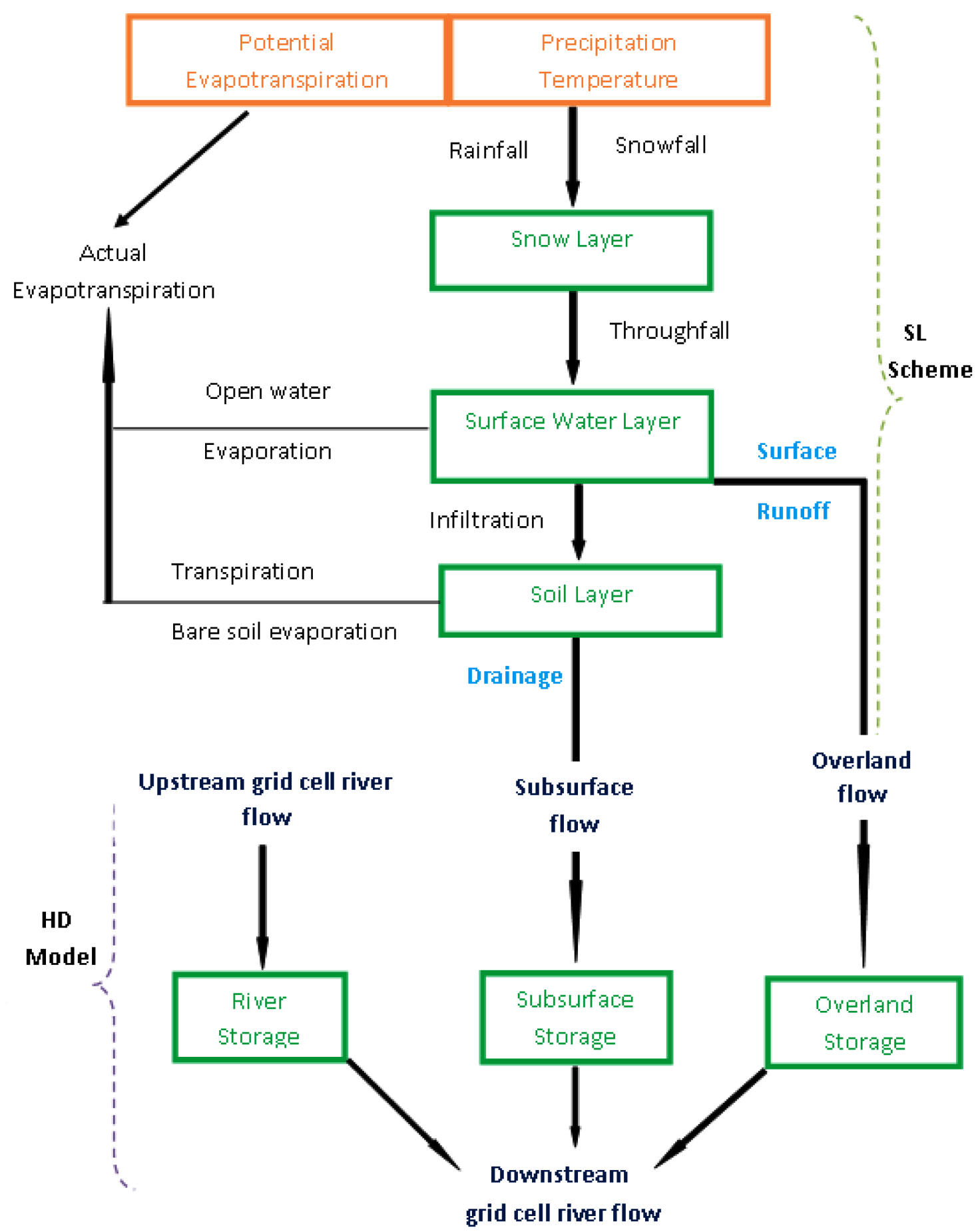

Figure 2. Structure of MPI-HM. Orange boxes indicate input variables, green boxes are water storages, and black arrows indicate water fluxes.

$$
\mathrm{NSE}=1-\frac{\sum_{j}\left(Q_{o}^{j}-Q_{s}^{j}\right)^{2}}{\sum_{j}\left(Q_{o}^{j}-\bar{Q}_{o}^{j}\right)^{2}}
$$

Percent Bias (PBIAS): it is used to estimate the model error 


$$
\text { PBIAS }=\frac{\sum_{j=1}^{n}\left(Q_{s}^{j}-Q_{o}^{j}\right)}{\sum_{j=1}^{n}\left(Q_{o}^{j}\right)} \times 100
$$

$Q_{o}^{j}$ denotes the observed discharge at the month j, $Q_{s}^{j}$ is the simulated one, and $\bar{Q}_{o}^{j}$ is the averaged observed streamflow. NSE ranges from $-\infty$ to 1.0 , with high values indicating better agreement. NSE $=1$ indicates a perfect match of simulated and observed data; NSE $=0$ corresponds to the model predictions matching the mean of the measured data, and NSE $<0$ shows that the measured mean is a better predictor than the model [39].

The PBIAS measures the tendency of the simulated variable to be larger or smaller than the corresponding observed value, its optimal value is 0.0 , and positive values indicate a tendency for over-estimation whereas negative values indicate a tendency for under-estimation [40].

\subsection{Simulation Analyses}

The analyses have been mainly focused on the seasonal cycles of river discharge, runoff, actual and potential evapotranspiration, soil moisture and precipitation. In addition, the seasonal spatial variability was investigated from July to October (JASO) which represents the high flow period. The changes represent the differences between the scenario period (2071-2100) and the reference period (1971-2000). Then, the change of available water resources which depends mainly on mean annual runoff is estimated as following:

$$
\Delta \mathrm{AW}=\frac{\left(R_{\text {scen }}-R_{\text {ref }}\right)}{\left(R_{\text {ref }}-\mathrm{EWR}\right)} \times 100
$$

$R_{\text {scen }}$ is the annual mean runoff in the scenario period $R_{\text {ref }}$ denotes the annual mean runoff in the reference period, and EWR is the Environmental Water Requirements that represents 30\% of the mean annual runoff in the basin [41]. Thus, Equation (3) can be simplified to:

$$
\Delta \mathrm{AW}=\frac{\left(R_{\text {scen }}-R_{\text {ref }}\right)}{\left(0.7 R_{\text {ref }}\right)} \times 100
$$

\section{Results and Discussion}

\subsection{Precipitation Biases and Changes}

This section assesses mainly the biases and changes of precipitation that is one the most important climate forcing data of the MPI-HM model. Then, bias corrected and uncorrected simulations are compared in order to see how their different variations may affect the hydrological simulations. Figure 3 shows the precipitation biases for uncorrected and bias corrected data during the reference period.

The wet biases during the main rain season (Figure 3(b)) and dry biases during the post and pre-monsoon in the uncorrected data have been removed in the corrected data (Figure 3(a)). Thus, the bias correction has well improved the variations of precipitation. This result is similar to that found also in the other forcing data, i.e. temperature and potential evapotranspiration (not shown). As for the projected precipitation changes (Figure 4), no substantial change in rainfall occurs from November to March for all datasets in all scenarios.

However, a general decrease of precipitation is found in the summer period (particularly in RCP8.5). This decrease is higher in the uncorrected data than in the bias corrected data.

The climate change signal exhibits the same tendency of decrease and increase of precipitation, except in September where a noticeable increase is found in the uncorrected data with RCP4.5. The bias correction tends to reduce the magnitude of the climate change signal of precipitation over the USB. These differences in magnitude may also affect the hydrological simulations by using these data as climate forcing. In addition, the PET is projected to increase in all months for all data (not shown) by the end of $21^{\text {st }}$ century. Then, the decrease of precipitation combined with the increase of PET is likely to considerably affect the water resources in the USB.

\subsection{Evaluation of River Discharge Simulations during the Present Day Climate}

The MPI-HM river discharge simulations are evaluated by comparing simulated and observed hydrographs. The 


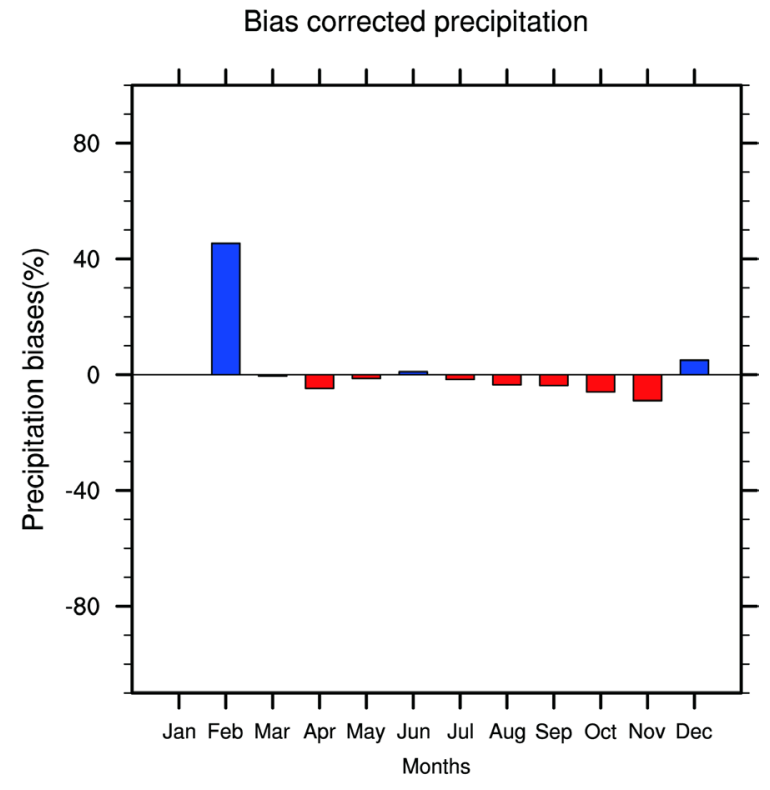

(a)

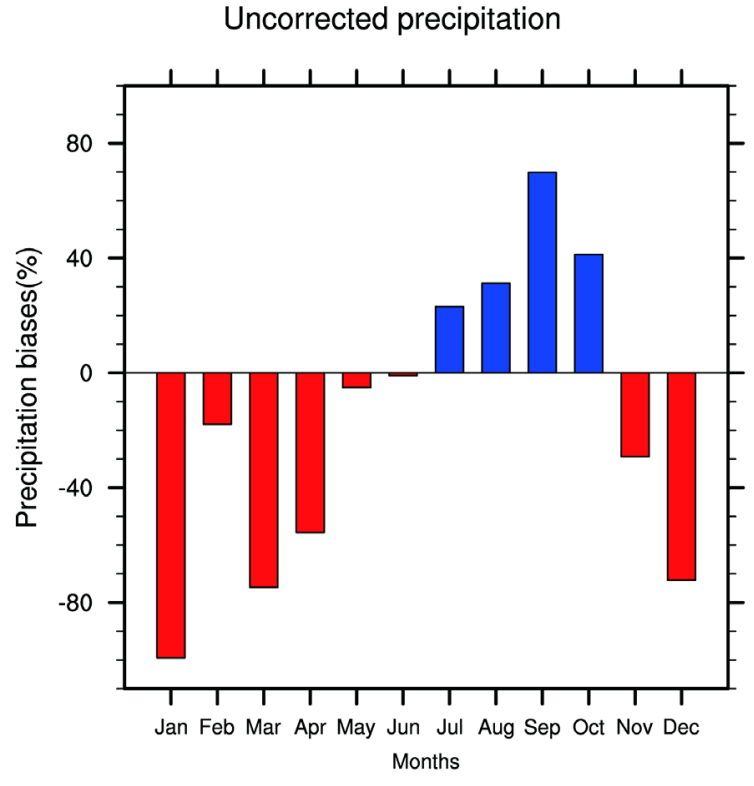

(b)

Figure 3. Precipitation biases of bias corrected (a) and uncorrected (b) precipitation.

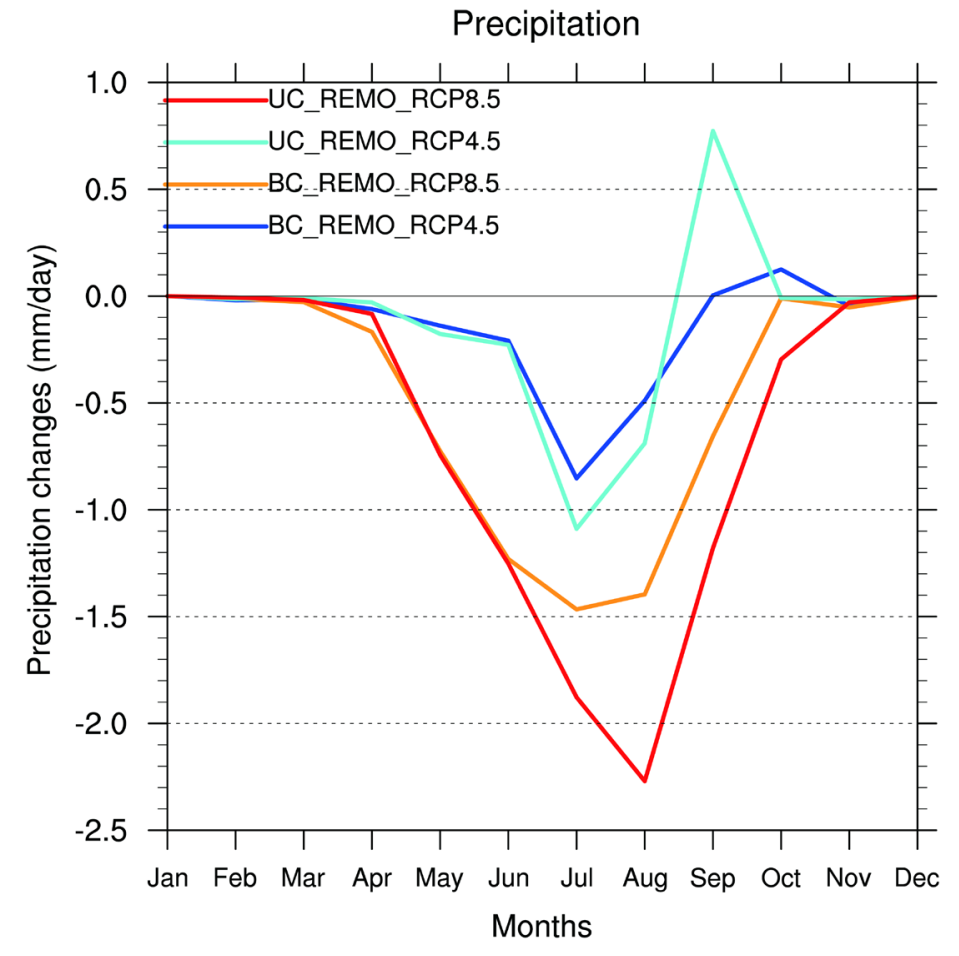

Figure 4. Precipitation changes of bias corrected and uncorrected simulations.

main goal within this section is to assess whether the bias corrected input enables a better reproduction of observed river regimes, and how the biases of climate forcing data affect simulated river discharge. In Figure 5(a), the simulated mean river discharge is compared to observed mean discharge during the reference period (19712000) at the outlet of the USB (Bakel). This figure demonstrates a clear improvement of simulated discharge 
when using bias corrected input. The uncorrected data highly overestimate the monthly discharge. During the dry season (January to June), the corrected data tend to overestimate the low flow and then slightly underestimate the beginning of high flow (July-August). The overestimation during the dry season may be due to the limitation of the hydrology model in properly handling extreme dry climate. As for the low flows $\left(10^{\text {th }}\right.$ percentile) and high flows $\left(90^{\text {th }}\right.$ percentile) presented in Figure 5(b) and Figure 5(c), respectively, the model largely overestimates the river flows by uncorrected data forcing as well. Using bias corrected input, the peak flow in September is well captured although the model overestimates the low flows in the dry season (Figure 5(b)). The huge biases from the uncorrected data input are related to the wet biases of uncorrected precipitation (as seen in Section 3.1). In addition, an underestimation of ET could also contribute to the overestimation of river discharge during the main rainy season.

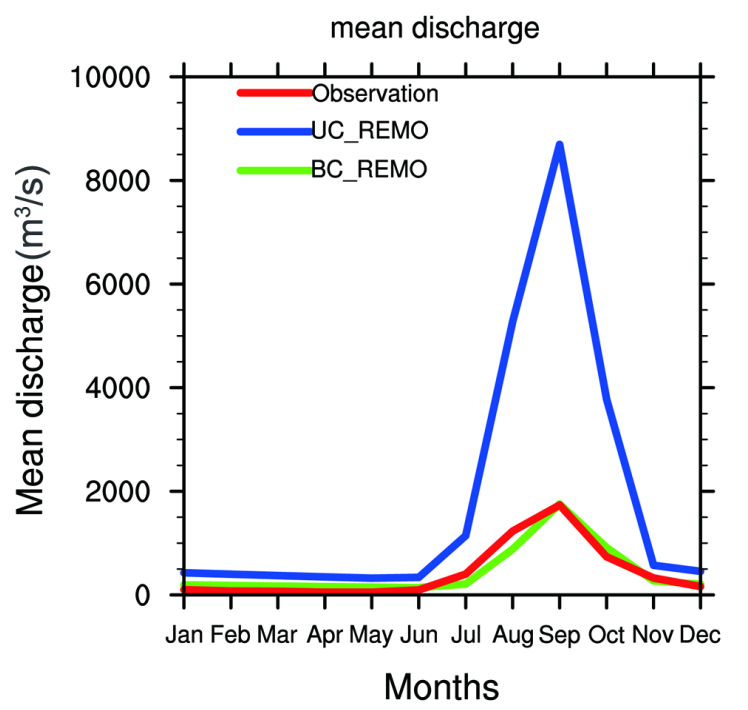

(a)

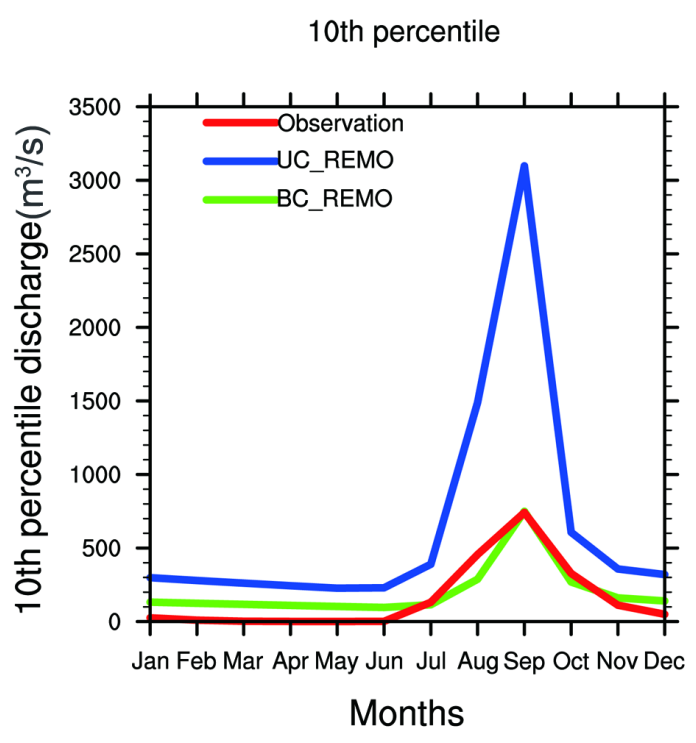

(b)

90th percentile

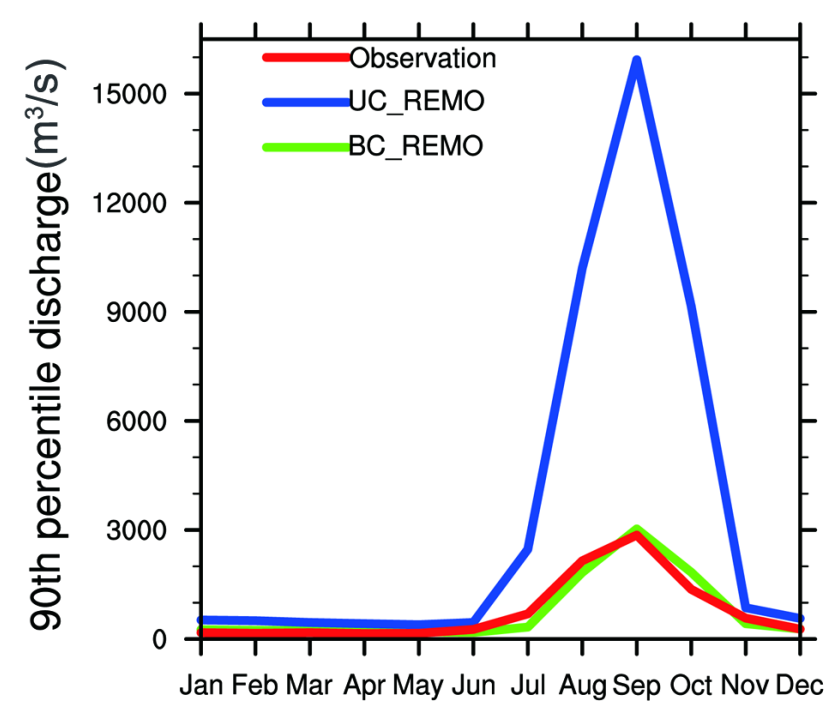

Months

(c)

Figure 5. Simulated and observed mean (a) $10^{\text {th }}$ percentile (b) and $90^{\text {th }}$ (c) percentile of river discharge at Bakel. 
Moreover, the observations are affected by flow regulation at the Manantali dam (upstream), which is not considered in the MPI-HM and might explain a part of the mismatch. The results show that the major differences of simulations occur during the high flow period with very huge values in the uncorrected data.

\subsection{Model Performance}

The model performance is evaluated by using the simulated mean monthly discharge. A Nash-Sutcliffe Efficiency coefficient of 0.92 is found between the simulated and the observed streamflow with bias corrected input. This high efficiency shows a good agreement between both datasets, indicating the chosen model combination (REMO + MPI-HM) is able to reproduce well the timing and the magnitude of observed streamflows. However, with the uncorrected input the efficiency is -21.98 that shows how far the simulation deviates to the observation. Furthermore, the PBIAS of bias corrected input is $3.88 \%$, which shows that the simulated discharge slightly deviate from those observed; by contrast to the uncorrected input where the PBIAS is up to $300 \%$ which depicts the huge overestimation of the model.

Hence, in this evaluation part, the bias corrected input provides realistic river discharge simulations. Therefore, bias correction is useful for a better representation of present day river discharge, so that it can help to reconstruct historical mean streamflows which are fundamental bases for future adaptations strategies planning.

\subsection{Potential Changes of Hydrological Variables with and without Bias Correction}

This section focuses mainly on the potential changes of river discharge, runoff, evapotranspiration, soil moisture by the end of $21^{\text {st }}$ century (2071-2100) under RCPs 4.5 and 8.5. In addition, the change of the projected signal from corrected and uncorrected input is considered in order to see if the bias correction alters the climate change signal.

\subsubsection{Monthly River Discharge Changes}

The changes in river discharge at the upper basin outlet (Bakel) and its $10^{\text {th }}$ and $90^{\text {th }}$ percentiles changes are presented in Figure 6. For all simulations, a general decrease is found, particularly in RCP8.5, except for August and September where an increase is found in RCP4.5. The decrease is less pronounced for the low flows than the high flows, and the RCP4.5 low flows show even a slightly increase during the peak flows period. This increase can be explained by lower evapotranspiration and small increase of precipitation. The bias corrected input neither substantially changes the signal in the mean discharge nor do the signals for low and high flows, even though slight differences exist in term of magnitude.

\subsubsection{Runoff Seasonal Change}

Figure 7 displays the seasonal change of runoff from July to October. Considerable decrease of runoff is found in the majority of the basin where the decrease reaches $-80 \%$ in the eastern basin with RCP8.5. With this later scenario, the runoff decline is higher in the uncorrected data than in the bias corrected simulation. As with the moderate scenario (RCP4.5), it is noticeable also that runoff is likely to decrease in the USB, except localized parts such as the mountainous areas where slight increase is depicted. The runoff decrease found over the basin in all scenarios and data is more related to the decline of precipitation and higher evaporation. Additionally, the bias corrected and the uncorrected simulations present similar spatial pattern of the climate change signal in both scenarios. However, small differences exist in the magnitude of the projected signals of both simulations.

\subsubsection{Evapotranspiration Seasonal Change}

The seasonal change of actual evapotranspiration presented in Figure 8 shows a decrease of ET from $12 \mathrm{~N}$ to $17.5 \mathrm{~N}$ for uncorrected and bias corrected data with RCP8.5 where the peak decrease reaches $-40 \%$ in the northern basin in both data. As with RCP4.5, a small decrease ( $-10 \%$ to $0 \%$ ) is found south of latitude $13 \mathrm{~N}$ for both datasets where the northern basin may face a decrease of $-10 \%$. The decrease of ET can be explained by the decline of soil moisture content. Furthermore, no change is found in the southern basin for all data and scenarios. From these results, it is noticeable that the bias corrected data have the same spatial pattern of the projected climate change signal as the uncorrected data. However, slight differences occur in the magnitude of the signal that seems to be reduced by the bias correction. 

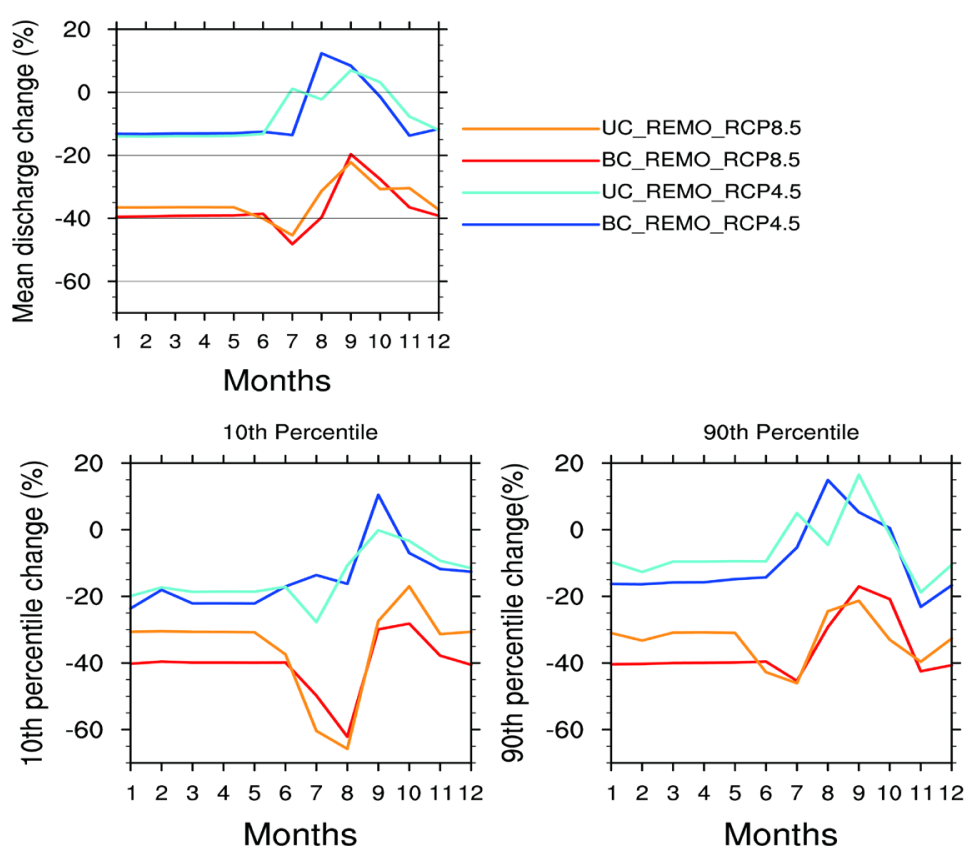

Figure 6. Mean monthly discharge change and percentiles $\left(10^{\text {th }}\right.$ and $\left.90^{\text {th }}\right)$ river discharge changes.
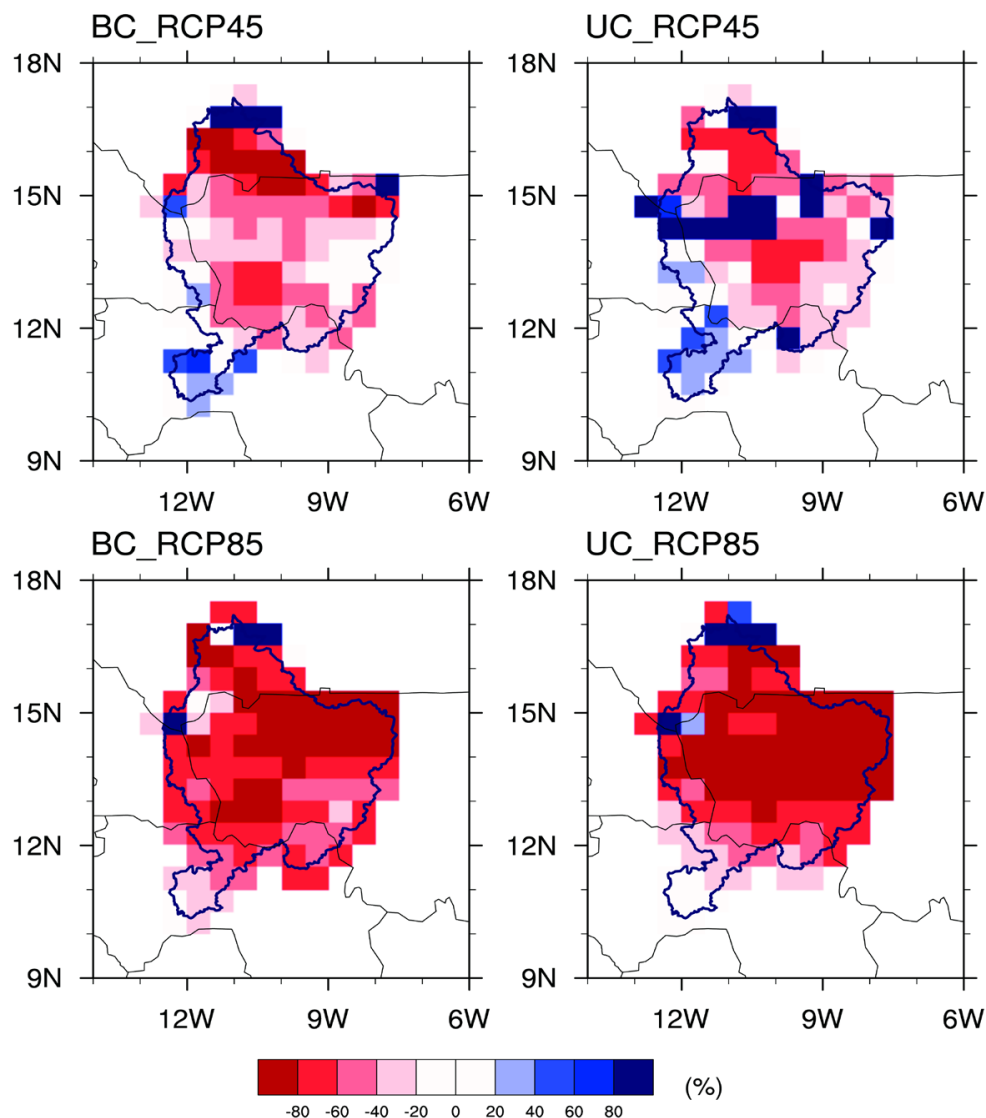

Figure 7. Seasonal changes of total runoff [UC: uncorrected, BC: bias corrected]. 

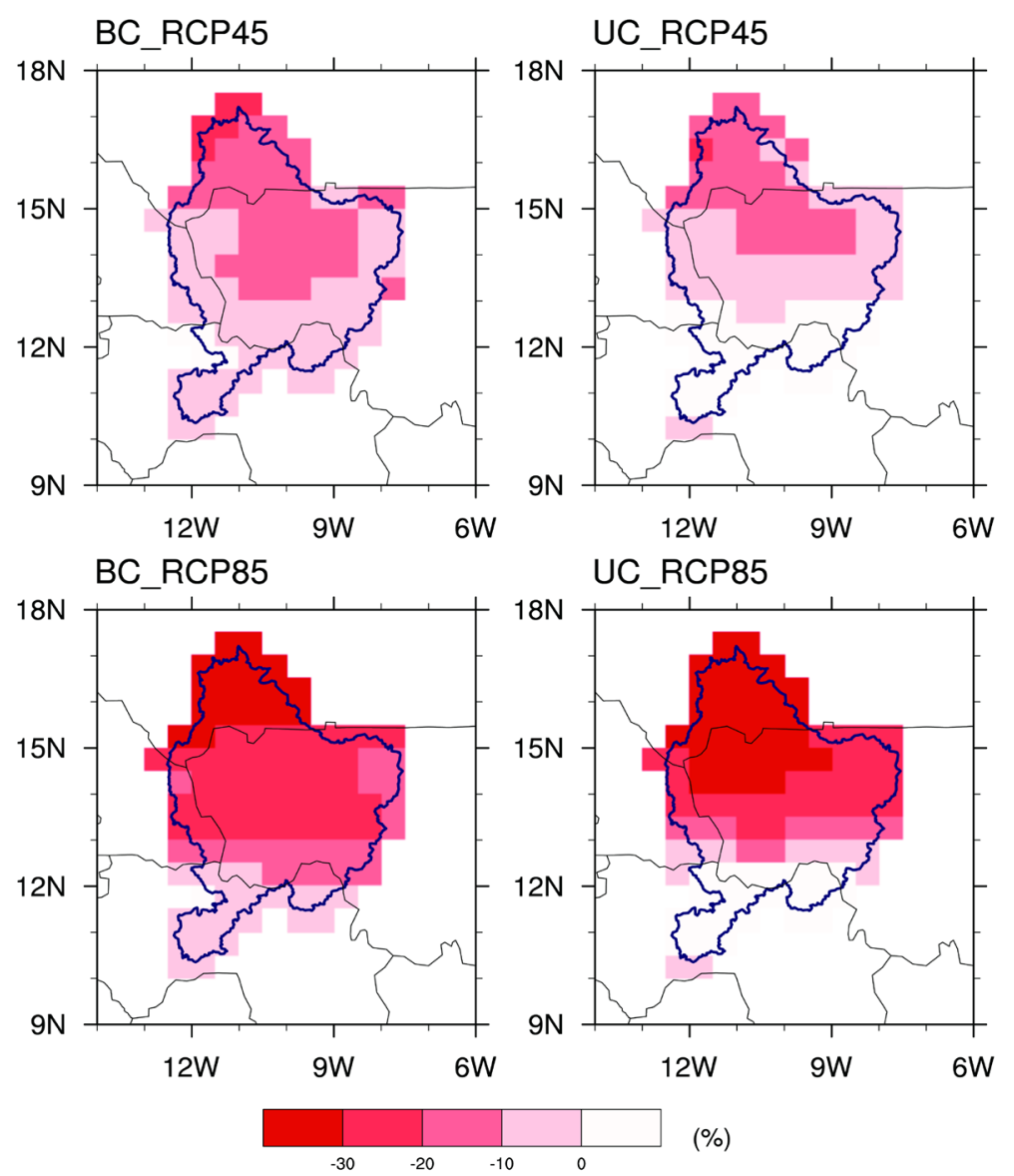

(\%)

Figure 8. Seasonal changes of evapotranspiration [UC: uncorrected, BC: bias corrected].

\subsubsection{Soil Moisture Seasonal Change}

Figure 9 displays the seasonal change of soil moisture. By the end of $21^{\text {st }}$ century, the soil water content is projected to drastically decrease over the majority of the basin from the central to the northern part ( $-40 \%$ to $-10 \%)$ in RCP8.5 for bias corrected and uncorrected data. The soil moisture decrease ranges from $-20 \%$ to $10 \%$ in the moderate scenario (RCP4.5) for both simulations. This decrease is due to the decrease of precipitation and the increase of temperature. As seen previously with ET changes, similar spatial pattern is found in the climate change signal of soil moisture between the raw and corrected simulations. This shows that the projected signal is not altered by the bias correction.

\subsubsection{Changes in the Seasonal Cycle of Evapotranspiration, Soil Moisture, and Runoff}

The seasonal cycle changes of soil moisture, evapotranspiration and runoff are shown in Figure 10. Soil moisture and evapotranspiration are generally decreasing in all data and scenarios. The decrease is more pronounced with RCP8.5 than with RCP4.5. The maximum ET changes are reached in June and November ( $-0.8 \mathrm{~mm} /$ day) for all data. This is mainly related to the increasing temperatures whose changes also peak during these months. The rising temperatures increase the atmospheric water demand and, thus, enhance evaporation. In case of soil moisture decrease, the peaks are reached in September with RCP4.5 $(-50 \mathrm{~mm})$ and RCP8.5 $(-135 \mathrm{~mm})$ for uncorrected and bias corrected simulations. Hence, the climate change signal within the same scenario has a similar tendency in both data. As for runoff, the main changes (decreases) occur during the period of high flows (JASO) for all simulations and scenarios. In the uncorrected data, the changes are higher in RCP8.5 ( -0.8 $\mathrm{mm} /$ day) than in the corrected data $(-0.2 \mathrm{~mm} /$ day). With RCP4.5 scenario, the potential change of runoff signal with bias corrected input is very small by comparison to the runoff signal with uncorrected climate input. It is 

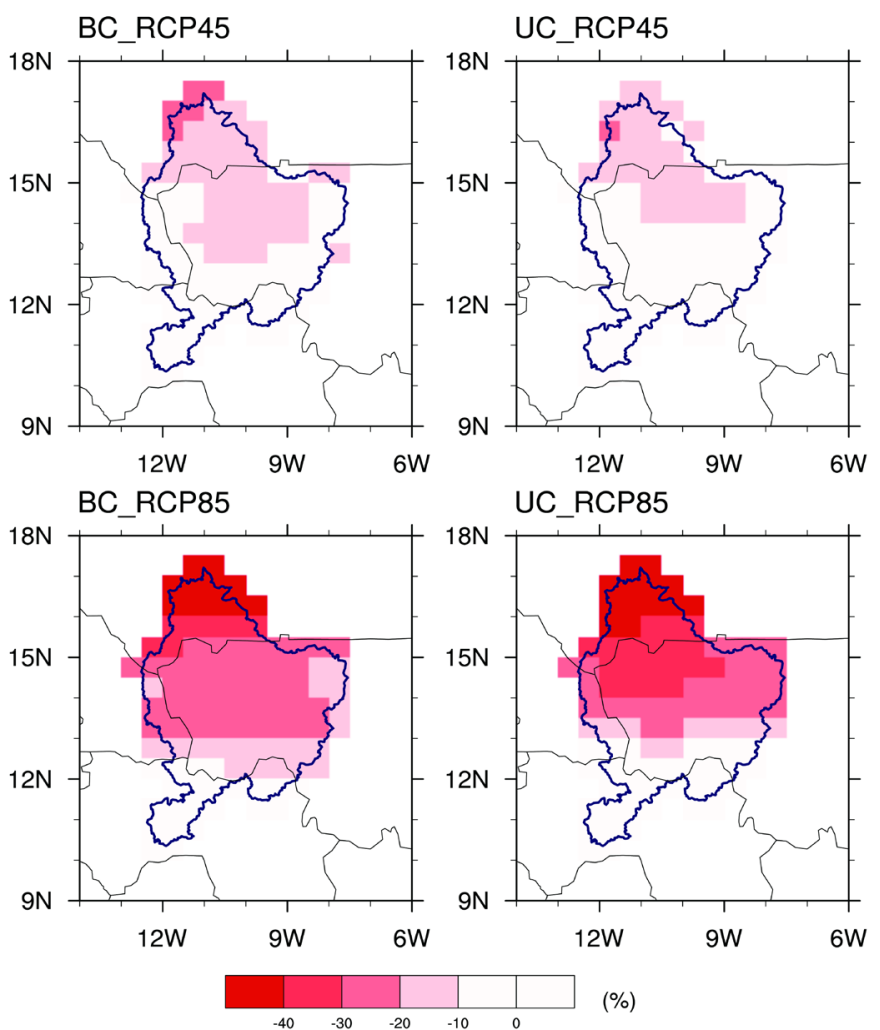

Figure 9. Seasonal changes of soil moisture [UC: uncorrected, BC: bias corrected].
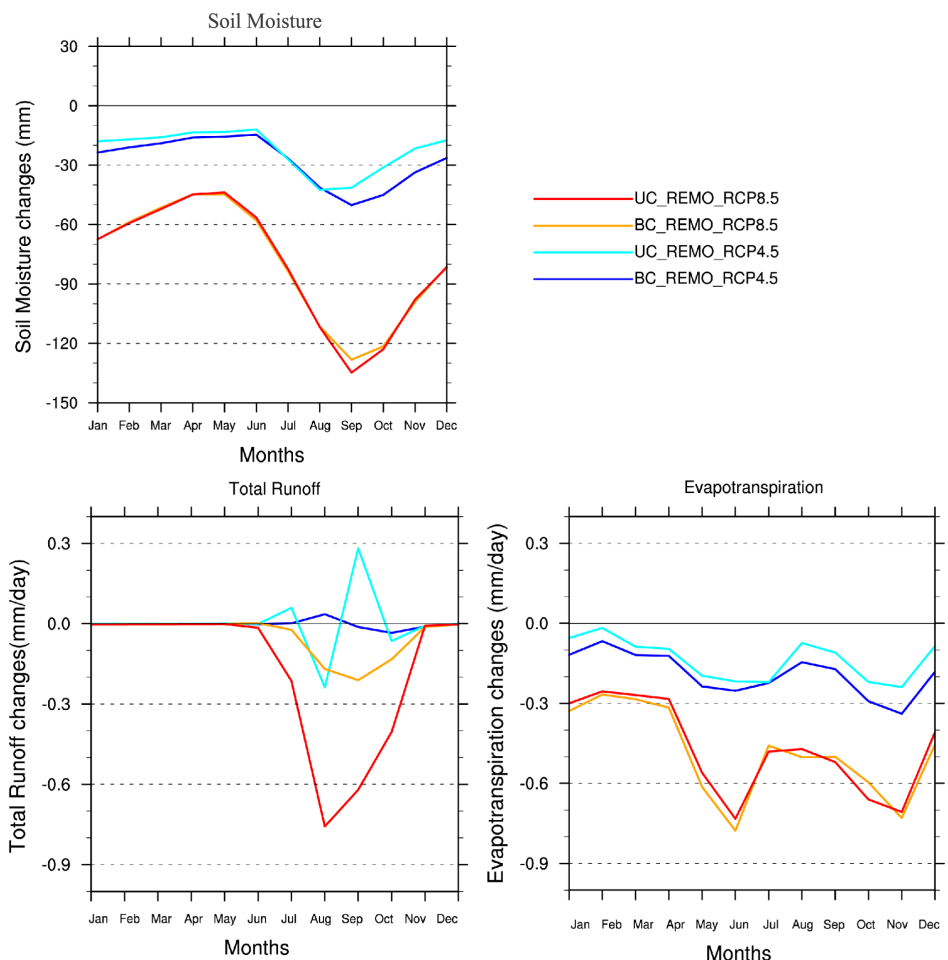

Figure 10. Climatological changes of evapotranspiration, runoff, and soil moisture [UC: uncorrected, BC: bias corrected]. 
noticeable with this later scenario that the uncorrected data depict two noticeable runoff peaks in August (increase) and September (decrease); these peaks are not found with corrected input. This later finding shows that the bias correction may change the projected runoff signal in some months.

\subsubsection{Annual Changes of Available Water Resources}

Figure 11 clearly shows that by the end of $21^{\text {st }}$ century, available water resources are likely to decrease drastically in the majority of the basin, particularly under RCP8.5 (where the peak reaches $-100 \%)$. This decrease is enhanced northward and becomes more acute in the most northeast part. Consistent with results mentioned above, no change of available water resources is found around the Guinean highlands, except for the uncorrected input under RCP4.5. In some localized parts of the basin, slight increases are found particularly in the uncorrected data (RCP4.5). All datasets and both scenarios exhibit similar spatial pattern. The decrease of available water follows the change pattern of runoff which is affected by the decrease of precipitation and the increase of potential evapotranspiration. Thus, the bias correction can alter the climate change signal of available water resources in some specific localities, but the spatial pattern is generally preserved.

\section{Conclusions}

An assessment of climate change impacts on water resources in the USB has been carried out. Despite considerable progress in recent years, output of both global and regional circulation models is still afflicted with biases to a degree that precludes its direct use, especially in climate change impact studies [42]. Then, to cope with this issue, bias correction is often used in hydrological impact studies although for specific locations and
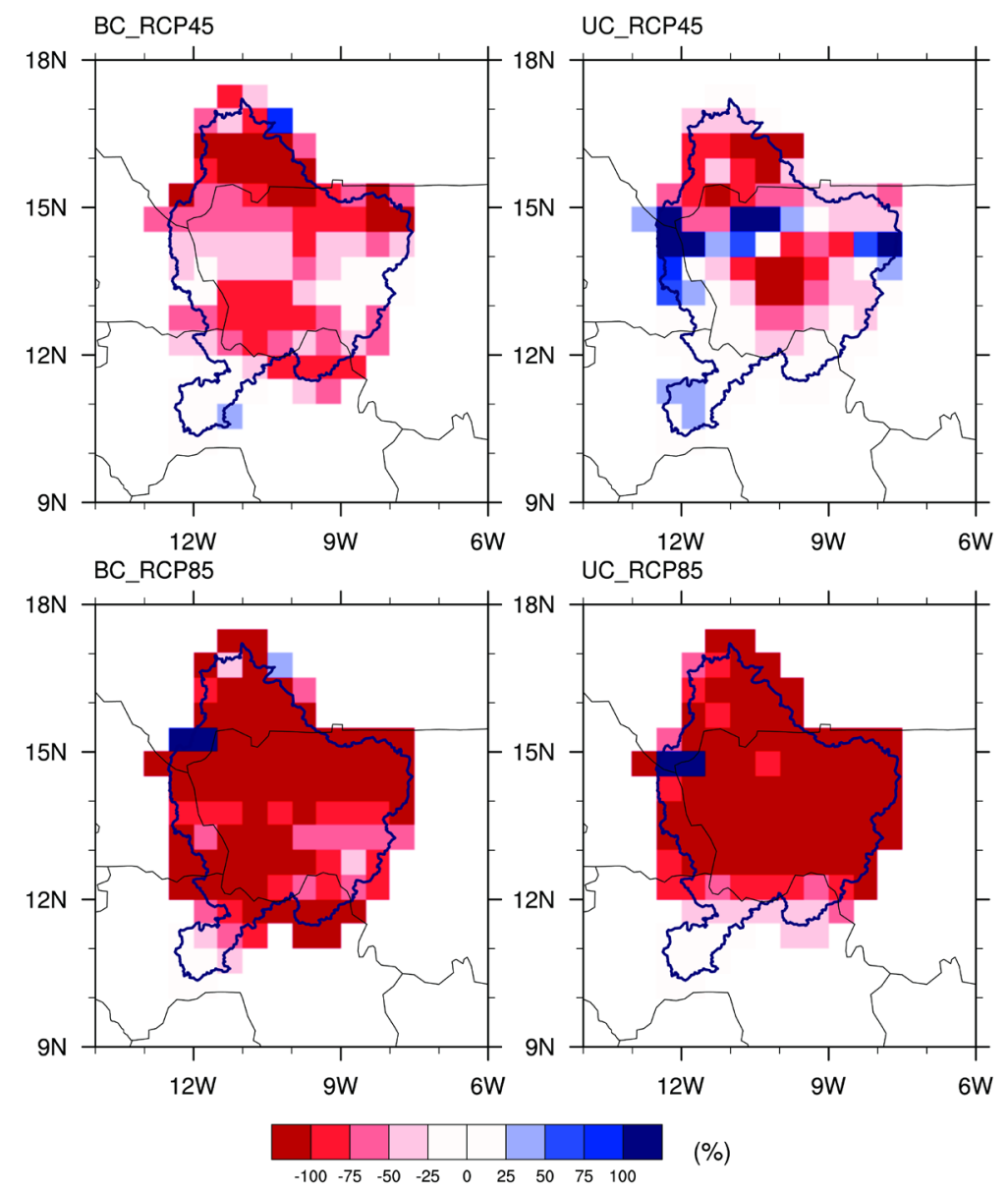

Figure 11. Available water resources changes [UC: uncorrected, BC: bias corrected]. 
seasons it may affect the climate change signal [17]. For these reasons, bias corrected and uncorrected climate data from the regional climate model REMO were used as input for the MPI-HM model to simulate river discharge, runoff, soil moisture and evapotranspiration. This is in agreement with the work of [43] who recommended presenting both results with and without bias correction in situations where only a few climate simulations are used in case that the climate change signals of outliers can be modified by bias correction. The global MPI-HM model parameters were optimized for local conditions of the USB in order to better capture the river flow variations. The results during the historical period (1971-2000) show that the bias corrected input give better representation of the river flow regimes at the outlet of the upper basin (Bakel) in the seasonal cycle. The same applies to the simulation of low flows $\left(10^{\text {th }}\right.$ percentile) and high flows $\left(90^{\text {th }}\right.$ percentile), thereby showing a slight overestimation of stream flow during the dry season. This can be related to the influence of other global parameters for which a tuning to local conditions might be necessary, or by missing processes such as the representation of soil crusts or human impacts. The results from uncorrected climate input are largely overestimated, which indicates the necessity of the bias correction. In this primary part, we conclude that the bias correction of precipitation and temperature has a great added value in reproducing present day river flows.

Then, by the end of $21^{\text {st }}$ century (2071-2100) under the RCPs 4.5 and 8.5, a general decrease of river discharge, runoff, actual evapotranspiration, soil moisture is projected even though there are some localized increases in some parts of the basin (particularly in Guinean highlands) with the uncorrected simulations. This decrease is mainly related to the decline of precipitation. The most extremes changes of soil moisture, ET, and runoff are likely to occur in the northern basin which is the driest and hottest part of the USB. Additionally, the available water resources exhibit substantial decrease (from $-100 \%$ to $-25 \%$ ) in the majority of the basin for all data, except the Guinean highlands where an increase (50\%) is found under RCP4.5 in the uncorrected data. The comparison of results from uncorrected and bias corrected input (in all variables) demonstrates that the bias correction does not substantially change the signal of future changes of hydrological variables for both scenarios over the Upper Senegal Basin even though there are slight differences in term of magnitude of the projected signal in some part of the basin.

The projected changes over the USB are associated with various sources of uncertainties, especially those arising from the choice of the various models used in the climate model-hydrology model modeling chain. These comprise the driving GCM, MPI-ESM-LR, the RCM REMO used for downscaling and the hydrological model MPI-HM. In addition, the effect of the bias correction technique is another source of uncertainty. These uncertainties need to be taken into account when interpreting the results. To reduce these uncertainties, it would be desirable to conduct analogous hydrological simulations with different components of the modeling chain, i.e. using different RCM outputs, different bias correction techniques, and different hydrological models, which would enable uncertainty analyses in future investigations.

Furthermore, general improvements will be needed such as implementation of soil crusting and a deeper soil water layer into the MPI-HM which might result in better representation of the hydrological regimes. The implementation of a deeper layer will allow more water to infiltrate into the soil, and increase the bucket from which the more slow process of drainage occurs. This will reduce the surface runoff that dominates the flows during the high flow period where the overestimation mainly occurs. Implementing the effect of soil crusting can take into account the quick runoff commonly caused by rainstorms over crusted areas in very dry conditions. We recommend also including the impacts of human activities and land uses changes on river flow for further investigations. The implementation of human activities such as the Manantali dam where a lot of water evaporates from its reservoir, will take into account the water losses from this dam reservoir, the denaturalized flow and reduce also the overestimation of river flow because this evaporation is currently not included in MPI-HM. In this semi-arid region, the degradation of the natural vegetation for farming, agricultural, and urban purposes, reduce infiltration and soil water holding capacity. These situations are likely to be exacerbated in the future and can enhance runoff, so that taking those processes into account will allow for a better representation of current and potential future flow regimes.

\section{Acknowledgements}

The authors thank the German Federal Ministry of Education and Research (BMBF) for funding the West African Science Service Center on Climate Change and Adapted Land Use (WASCAL) that has funded this work, and the University of Abomey Calavi-Benin which hosts the Graduate Research Program of Climate Change 
and Water Resources. We are further thankful to the THY group (Max Planck Institute, Hamburg, Germany) and the Climate Service Center (Hamburg, Germany) where this work was mainly conducted and for their various supports and to Christopher Moseley (Max Planck Institute, Hamburg, Germany) for his great technical assistance.

\section{References}

[1] Bates, B.C., Kundzewicz, Z.W., Wu, S. and Palutikof, J.P. (2008) Climate Change and Water. Technical Paper of the Intergovernmental Panel on Climate Change, IPCC, Geneva.

[2] IPCC (2014) Climate Change: Impacts, Adaptation, and Vulnerability. Part B: Regional Aspects. Contribution of Working Group II to the Fifth Assessment Report of the Intergovernmental Panel on Climate Change (Barros, V.R., Field, C.B., Dokken, D.J., Mastrandrea, M.D., Mach, K.J., Bilir, T.E., Chatterjee, M., Ebi, K.L., Estrada, Y.O., Genova, R.C., Girma, B., Kissel, E.S., Levy, A.N., MacCracken, S., Mastrandrea, P.R. and White, L.L., Eds.). Cambridge University Press, Cambridge and New York.

[3] Ardoin-Bardin, S., Dezetter, A., Servat, E., Paturel, J.E., Mahé, G., Niel, H. and Dieulin, C. (2009) Using General Circulation Model Outputs to Assess Impacts of Climate Change on Runoff for Large Hydrological Catchments in West Africa. Hydrological Sciences Journal, 54, 77-89. http://dx.doi.org/10.1623/hysj.54.1.77

[4] Karambiri, H., García Galiano, S.G., Giraldo, J.D., Yacouba, H., Ibrahim, B., Barbier, B. and Polcher, J. (2011) Assessing the Impact of Climate Variability and Climate Change on Runoff in West 30 Africa: The Case of Senegal and Nakambe River Basins. Atmospheric Science Letters, 12, 109-115. http://dx.doi.org/10.1002/asl.317

[5] McCartney, M., Forkuor, G., Sood, A., Amisigo, B., Hattermann, F. and Muthuwatta, L. (2012) The Water Resource Implications of Changing Climate in the Volta River Basin. IWMI Research Report 146, Colombo.

http://dx.doi.org/10.5337/2012.219

[6] Ruelland, D., Ardoin-Bardin, S., Collet, L. and Roucou, P. (2012) Simulating Future Trends in Hydrological Regime of a Large Sudano-Sahelian Catchment under Climate Change. Journal of Hydrology, 424-425, 207-216. http://dx.doi.org/10.1016/j.jhydrol.2012.01.002

[7] Faramarzi, M., Abbaspour, K.C., Ashraf Vaghefi, S., Farzaneh, M.R., Zehnder, A.J.B., Srinivasan, R. and Yang, H. (2013) Modeling Impacts of Climate Change on Freshwater Availability in Africa. Journal of Hydrololgy, 480, 85-101. http://dx.doi.org/10.1016/j.jhydrol.2012.12.016

[8] Mahe, G., Lienou, G., Descroix, L., Bamba, F., Paturel, J. E., Laraque, A., Meddi, M., Habaieb, H., Adeaga, O., Dieulin, C., Chahnez Kotti, F. and Khomsi, K. (2013) The Rivers of Africa: Witness of Climate Change and Human Impact on the Environment. Hydrological Processes, 27, 2105-2114. http://dx.doi.org/10.1002/hyp.9813

[9] Aich, V., Liersch, S., Vetter, T., Huang, S., Tecklenburg, J., Hoffmann, P., Koch, H., Fournet, S., Krysanova, V., Müller, E.N. and Hattermann, F.F. (2014) Comparing Impacts of Climate Change on Streamflow in Four Large African River Basins. Hydrology and Earth System Sciences, 18, 1305-1321. http://dx.doi.org/10.5194/hess-18-1305

[10] IPCC (2014) Climate Change: Impacts, Adaptation, and Vulnerability. Part A: Global and Sectoral Aspects. Contribution of Working Group II to the Fifth Assessment Report of the Intergovernmental Panel on Climate Change (Field, C.B., Barros, V.R., Dokken, D.J., Mach, K.J., Mastrandrea, M.D., Bilir, T.E., Chatterjee, M., Ebi, K.L., Estrada, Y.O., Genova, R.C., Girma, B., Kissel, E.S., Levy, A.N., MacCracken, S., Mastrandrea, P.R. and White, L.L., Eds.). Cambridge University Press, Cambridge and New York.

[11] ENDA-TM (2007) Climate Change Adaptation and Water Resources Management in West Africa. Synthesis Report-WRITESHOP.

[12] Oyebande, L. and Odunuga, S. (2010) Climate Change Impact on Water Resources at the Transboundary Level in West Africa: The Cases of the Senegal, Niger and Volta Basins. The Open Hydrology Journal, 4, 163-172. http://dx.doi.org/10.2174/1874378101004010163

[13] Osorio, G.J.D. and Galiano, G.S.G. (2012) Non-Stationary Analysis of Dry Spells in Monsoon Season of Senegal River Basin Using Data from Regional Climate Models (RCMs). Journal of Hydrology, 450-451, 82-92. http://dx.doi.org/10.1016/j.jhydrol.2012.05.029

[14] Fowler, H.J., Blenkinsop, S. and Tebaldi, C. (2007) Linking Climate Change Modelling to Impacts Studies: Recent Advances in Downscaling Techniques for Hydrological Modelling. International Journal of Climatology, 27, 15471578. http://dx.doi.org/10.1002/joc.1556

[15] Roosmalen, V., Lieke, S., Torben, O.J., Karsten, H.C. and Roosmalen, J.H. (2011) Comparison of Hydrological Simulations of Climate Change Using Perturbation of Observations and Distribution-Based Scaling. Vadose Zone Journal, 10, 136-150. http://dx.doi.org/10.2136/vzj2010.0112

[16] Beven, K. and Feyen, J. (2002) The Future of Distributed Modelling. Hydrological Processes, 16, 169-172. 
http://dx.doi.org/10.1002/hyp.325

[17] Hagemann, S., Chen, C., Haerter, J.O., Heinke, J., Gerten, D. and Piani, C. (2011) Impact of a Statistical Bias Correction on the Projected Hydrological Changes Obtained from Three GCMs and Two Hydrology Models. Journal of Hydrometeorology, 12, 556-578. http://dx.doi.org/10.1175/2011JHM1336.1

[18] Stisen, S., Jensen, K.H., Sandholt, I. and Grimes David, I.F. (2008) A Remote Sensing Driven Distributed Hydrological Model of the Senegal River Basin. Journal of Hydrology, 354, 131-148.

http://dx.doi.org/10.1016/j.jhydrol.2008.03.006

[19] OMVS (2000) Senegal River Basin, Guinea, Mali, Mauritania, Senegal. http://webworld.unesco.org/water/wwap/case_studies/senegal_river/senegal_river.pdf

[20] Jacob, D. and Podzun, R. (1997) Sensitivity Studies with the Regional Climate Model REMO. Meteorology and Atmospheric Physics, 63, 119-129. http://dx.doi.org/10.1007/BF01025368

[21] Stevens, B., Giorgetta, M., Esch, M., Mauritsen, T., Crueger, T., Rast, S., Salzmann, M., Schmidt, H., Bader, J., Block, K., Brokopf, R., Fast, I., Kinne, S., Kornblueh, L., Lohmann, U., Pincus, R., Reichler, T. and Roeckner, E. (2013) The Atmospheric Component of the MPI-M Earth System Model: ECHAM6. Journal of Advances in Modeling Earth Systems, 5, 146-172. http://dx.doi.org/10.1002/jame.20015

[22] Giorgi, F., Jones, C. and Asrar, G. (2009) Addressing Climate Information Needs at the Regional Level: The CORDEX Framework. World Meteorological Organization Bulletin, 58, 175-183. http://wcrp.ipsl.jussieu.fr/RCD_Projects/CORDEX/CORDEX_giorgi_WMO.pdf

[23] Gbobaniyi, E., Sarr, A., Sylla, M.B., Diallo, I., Lennard, C., Dosio, A., Dhiédiou, A., Kamga, A., Klutse, N.A.B., Hewitson, B., Nikulin, G. and Lamptey, B. (2013) Climatology, Annual Cycle and Interannual Variability of Precipitation and Temperature in CORDEX Simulations over West Africa. International Journal of Climatology, 34, 2241-2257. http://dx.doi.org/10.1002/joc.3834

[24] Jacob, D., Elizalde, A., Haensler, A., Hagemann, S., Kumar, P., Podzun, R., Rechid, D., Remedio, A.R., Saeed, F., Sieck, K., Teichmann, C. and Wilhelm, C. (2012) Assessing the Transferability of the Regional Climate Model REMO to Different Coordinated Regional Climate Downscaling Experiment (CORDEX) Regions. Atmosphere, 3, 181-199. http://dx.doi.org/10.3390/atmos3010181

[25] Haensler, A., Hagemann, S. and Jacob, D. (2011) The Role of Simulation Setup in a Long-Term High Resolution Climate Change Projection for Southern African Region. Theoretical and Applied Climatology, 106, 153-169. http://dx.doi.org/10.1007/s00704-011-0420-1

[26] Nikulin, G., Jones, C., Giorgi, F., Asrar, G., Cerezo-Mota, M., Christensen, O.B., Déqué, M., Fernandez, J., Hänsler, A., Meijgaard, E.V., Patrick Samuelsson, P., Sylla, M.B. and Sushama, L. (2012) Precipitation Climatology in an Ensemble of CORDEX-Africa Regional Climate Simulations. Journal of Climate, 25, 6057-6078. http://dx.doi.org/10.1175/JCLI-D-11-00375.1

[27] Piani, C., Weedon, G.P., Best, M., Gomes, S., Viterbo, P., Hagemann, S. and Haerter, J.O. (2010) Statistical Bias Correction of Global Simulated Daily Precipitation and Temperature for the Application of Hydrological Models. Journal of Hydrology, 395,199-215. http://dx.doi.org/10.1016/j.jhydrol.2010.10.024

[28] Ruti, P.M., Williams, J.E., Hourdin, F., Guichard, F., Boone, A., Van Velthoven, P., Favot, F., Musat, I., Rummukainen, M., Domínguez, M., Gaertner, M.Á., Lafore, J.P., Losada, T., Rodriguez de Fonseca, M.B., Polcher, J., Giorgi, F., Xue, Y., Bouarar, I., Law, K., Josse, B., Barret, B., Yang, X., Mari, C. and Traore, A.K. (2011) The West African Climate System: A Review of the AMMA Model Inter-Comparison Initiatives. Atmospheric Science Letters, 12, 116-122. http://dx.doi.org/10.1002/asl.305

[29] Stacke, T. and Hagemann, S. (2012) Development and Evaluation of a Global Dynamical Wetlands Extent Scheme. Hydrology and Earth System Sciences, 16, 2915-2933. http://dx.doi.org/10.5194/hess-16-2915-2012

[30] Hagemann, S. and Dümenil Gates, L. (2003) Improving a Subgrid Runoff Parameterization Scheme for Climate Models by the Use of High Resolution Data Derived from Satellite Observations. Climate Dynamics, 21, 349-359. http://dx.doi.org/10.1007/s00382-003-0349-x

[31] Hagemann, S. and Dümenil, L. (1998) A Parametrization of the Lateral Waterflow for the Global Scale. Climate Dynamics, 14, 17-31. http://dx.doi.org/10.1007/s003820050205

[32] Hagemann, S. and Dümenil, L. (1999) Application of a Global Discharge Model to Atmospheric Model Simulations in the BALTEX Region. Nordic Hydrology, 30, 209-230.

[33] Hagemann, S. and Dümenil Gates, L. (2001) Validation of the Hydrological Cycle ECMWF and NCEP Reanalyses Using the MPI Hydrological Discharge Model. Journal of Geophysical Research, 106, 1503-1510. http://dx.doi.org/10.1029/2000JD900568

[34] Chen, C., Haerter, J.O., Hagemann, S. and Piani, C. (2011) On the Contribution of Statistical Bias Correction to the Uncertainty in the Projected Hydrological Cycle. Geophysical Research Letters, 38, Article ID: L20403. 
http://dx.doi.org/10.1029/2011GL049318

[35] Hagemann, S., Chen, C., Clark, D.B., Folwell, S., Gosling, S.N., Haddeland, I., Hanasaki, N., Heinke, J., Ludwig, F., Voss, F. and Wiltshire, A.J. (2013) Climate Change Impact on Available Water Resources Obtained Using Multiple Global Climate and Hydrology Models. Earth System Dynamics, 4, 129-144. http://dx.doi.org/10.5194/esd-4-129-2013

[36] Hagemann, S. (2002) An Improved Land Surface Parameter Dataset for Global and Regional Climate Models. Report 336, Max-Planck-Institute for Meteorology, Hamburg.

[37] Hagemann, S. and Stacke, T. (2014) Impact of the Soil Hydrology Scheme on Simulated Soil Moisture Memory. Climate Dynamics. http://dx.doi.org/10.1007/s00382-014-2221-6

[38] Nash, J.E. and Sutcliffe, J.V. (1970) River Flow Forecasting through Conceptual Models Part I-A Discussion of Principles. Journal of Hydrology, 273, 282-290. http://dx.doi.org/10.1016/0022-1694(70)90255-6

[39] Legates, D.R. and McCabe Jr., G.J. (1999) Evaluating the Use of “Goodness-of-Fit” Measures in Hydrologic and Hydroclimatic Model Validation. Water Resources Research, 35, 233-241. http://dx.doi.org/10.1029/1998WR900018

[40] Gupta, H.V., Sorooshian, S. and Yapo, P.O. (1999) Status of Automatic Calibration for Hydrologic Models: Comparison with Multilevel Expert Calibration. Journal of Hydrologic Engineering, 4, 135-143. http://dx.doi.org/10.1061/(ASCE)1084-0699(1999)4:2(135)

[41] Smakhtin, V., Revenga, C. and Döll, P. (2004) A Pilot Global Assessment of Environmental Water Requirements and Scarcity. Water International, 29, 307-317. http://dx.doi.org/10.1080/02508060408691785

[42] Ehret, U., Zehe, E., Wulfmeyer, V., Warrach-Sagi, K. and Liebert, J. (2012) HESS Opinions “Should We Apply Bias Correction to Global and Regional Climate Model Data?” Hydrology and Earth System Sciences, 16, 3391-3404. http://dx.doi.org/10.5194/hess-16-3391-2012

[43] Muerth, M.J., Gauvin St-Denis, B., Ricard, S., Velázquez, J.A., Schmid, J., Minville, M., Caya, D., Chaumont, D., Ludwig, R. and Turcotte, R. (2013) On the Need for Bias Correction in Regional Climate Scenarios to Assess Climate Change Impacts on River Runoff. Hydrology and Earth System Sciences, 17, 1189-1204. http://dx.doi.org/10.5194/hess-17-1189-2013 